\title{
Bone Resorption in Tissue Culture. Factors Influencing the Response to Parathyroid Hormone*
}

\author{
Lawrence G. Raisz $\dagger$ \\ (From the Departments of Pharmacology and Medicine, University of Rochester School of \\ Medicine and Dentistry, Rochester, N. Y.)
}

Direct stimulation of bone resorption by parathyroid tissue extracts has been demonstrated in transplantation experiments $(2,3)$ and in tissue culture $(4,5)$. Since bone from rats previously given parathyroid extract could maintain a higher calcium concentration in the medium than controls when incubated in vitro (6), it seemed likely that direct stimulation of bone resorption in culture would also result in a movement of calcium from bone to medium. The present studies employ a technique for measuring such resorption in terms of the release of radioactive calcium previously incorporated in embryonic bone. This technique has provided a sensitive bioassay for parathyroid hormone preparations (1). However, many other factors can affect bone resorption in organ cultures. In the present experiments the effects of varying culture conditions, particularly $\mathrm{pH}$, calcium and phosphate concentrations, and oxygen tension, were studied. Sera from patients with abnormalities of parathyroid function were added to the culture medium to determine whether these had any direct effects or might alter the response to added parathyroid hormone. The effects of vitamin A, cortisol, triiodothyronine, and vitamin $\mathrm{D}$ were also studied alone and in combination with parathyroid hormone, since

* Submitted for publication June 18, 1964; accepted September 24, 1964.

This investigation was supported by a Clinical Pharmacology Award from the Burroughs-Wellcome Foundation and research grant AM-06205 from the National Institute of Arthritis and Metabolic Diseases, Bethesda, Md.

Presented in part to the American Federation for Clinical Research, Atlantic City, N. J., April 29, 1962, and to the American Society for Pharmacology and Experimental Therapeutics, Fall Meeting, San Francisco, Calif., August 11-15, 1963. A preliminary report of part of this work has been published (1).

† Work begun while a Special Research Fellow of the U. S. Public Health Service at the Strangeways Research Laboratory, Cambridge, England. these agents have previously been shown to affect bone in vivo (7-14), by local application (15, $16)$, or in tissue culture $(5,17-21)$.

\section{Methods ${ }^{1}$}

Preparation of tissue. Dating of pregnancy was assured by mating large numbers of Rochester Wistar rats for only 16 hours. Seventeen days later pregnant animals were injected with 300 to $500 \mu \mathrm{c}$ of $\mathrm{Ca}^{\alpha 5}$ as $\mathrm{CaCl}_{2}$ solution subcutaneously. On the nineteenth day, the injected rats were sacrificed, the embryos removed, and the forelimbs separated and kept in Eagle's medium (22) in a $150-\mathrm{mm}$ Petri dish at 5 to $10^{\circ} \mathrm{C}$ until dissection. With a binocular dissecting microscope, the radius and ulna were dissected free of muscle and the cartilaginous ends cut off. The bone shaft was washed three times with Eagle's medium before transfer to a culture vessel. The bone explant consisted of a thin tube of calcified bone matrix surrounding a core of calcified cartilage with discs of mature cartilage cells at each end (Figure 1). There was often beginning marrow cavity formation in 19-day embryos, but little hematopoietic tissue remained after washing.

Culture technique. Small embryo watch glasses were used, eight of which fitted into a $150-\mathrm{mm}$ glass Petri dish. The bones were placed on squares of Millipore filter resting on a metal screen so cut that $0.5 \mathrm{ml}$ of medium filled the culture vessel to the surface of the screen. The medium was a mixture of $50 \%$ serum and $50 \%$ modified Eagle's medium. The final calcium concentration in this medium was 7 to $9 \mathrm{mg}$ per $100 \mathrm{ml}$. When human serum was used, the final phosphate concentration was 3 to $4 \mathrm{mg}$ per $100 \mathrm{ml}$; when rat serum was used, the final phosphate concentration was 5 to $8 \mathrm{mg}$ per $100 \mathrm{ml}$.

The culture vessels were filled with medium and test substances and equilibrated with $5 \% \quad \mathrm{CO}_{2}, 20 \% \quad \mathrm{O}_{2}$, and $75 \% \mathrm{~N}_{2}$ at $37^{\circ} \mathrm{C}$ in a plastic chamber before the bones were explanted. The gas was bubbled through demineralized distilled water at the bottom of the chamber. The bottom of each Petri dish was lined with filter paper moistened with Eagle's medium containing phenol red. The change in color of this medium provided evidence that the cultures had equilibrated with $\mathrm{CO}_{2}$. After explantation the cultures were maintained

1 A more detailed description of methods and materials is available on request. 
TABLE I

Effect of parathyroid extract (PTE) and purified parathyroid hormone (PTH) on bone resorption in organ culture*

\begin{tabular}{|c|c|c|c|c|c|c|}
\hline \multirow[b]{3}{*}{ Material } & \multirow[b]{3}{*}{ Dose } & \multirow{3}{*}{$\begin{array}{l}\text { No. } \\
\text { experi- } \\
\text { ments }\end{array}$} & \multicolumn{4}{|c|}{ Treated/Control ratio } \\
\hline & & & \multicolumn{2}{|c|}{$\mathrm{Ca}^{45}$ release } & \multicolumn{2}{|c|}{ Medium Ca concentration } \\
\hline & & & Mean $\pm \mathrm{SE}$ & Range & Mean $\pm \mathrm{SE}$ & Range \\
\hline \multirow{5}{*}{ PTE } & $U / m l$ & & & & & \\
\hline & 1.0 & 16 & $2.34 \pm 0.16$ & $1.30-3.80$ & $1.12 \pm 0.02$ & $1.01-1.22$ \\
\hline & 0.3 & 2 & $2.57 \pm 0.07$ & $2.50-2.64$ & $1.11 \pm 0.02$ & $1.09-1.13$ \\
\hline & 0.1 & 16 & $1.67 \pm 0.06$ & $1.28-2.10$ & $1.05 \pm 0.01$ & $0.92-1.16$ \\
\hline & 0.01 & 5 & $\underline{1.10 \pm 0.04}$ & $1.02-1.22$ & $0.97 \pm 0.03$ & $0.87-1.04$ \\
\hline \multirow[t]{2}{*}{ PTH } & 0.3 & 6 & $2.76 \pm 0.05$ & $2.54-2.97$ & $1.14 \pm 0.01$ & $1.08-1.17$ \\
\hline & 0.1 & 6 & $2.09 \pm 0.21$ & $1.50-2.65$ & $1.07 \pm 0.03$ & $0.99-1.18$ \\
\hline
\end{tabular}

* Mean \pm standard error and range of values are given for all multiple-dose experiments in medium containing normal human serum. In each experiment four to six pairs of bones were used at each dose level. Treated/control ratios underlined once are significantly greater than 1.0 at $\mathrm{p}<0.05$; underlined twice, at $\mathrm{p}<0.01$.

under continuous gas flow in the closed chamber for 72 hours.

Analytic methods. At the end of cultivation the fluid was removed, and stable and radioactive calcium concentration in the medium of each culture was measured. Phosphate concentration (23) was measured in pools of four samples from each treatment and control group. $\mathrm{pH}$ was measured in pools of four samples after they had been re-equilibrated with $5 \% \mathrm{CO}_{2}$ at $37^{\circ} \mathrm{C}$. The bones were either fixed in Zenker's solution for histologic study or put in $0.5 \mathrm{ml}$ of $1 \mathrm{~N} \mathrm{HCl}$ to dissolve the bone mineral and measure its radioactivity. Stable calcium concentration was measured by Edathamil (EDTA) titration (24). Radioactive calcium was measured in an automatic liquid scintillation counter (25). Counting efficiency was 50 to $60 \%$ and did not vary by more than $5 \%$ in a given experiment for both samples of culture medium and $\mathrm{HCl}$ solution of bone.
Materials. 1) Parathyroid extract 2 (PTE, $100 \mathrm{U}$ per $\mathrm{ml})$ was added to the medium directly or after dilution in a solution containing $1.6 \%$ glycerol, $0.2 \%$ phenol, and $0.9 \% \mathrm{NaCl}$. The diluent solution alone was added to the medium cultivating control bones. 2) Parathyroid hormone $(\mathrm{PTH})$. A single sample of purified parathyroid hormone ${ }^{3}$ with an estimated potency of 2,500 $\mathrm{U}$ per $\mathrm{mg}$ was diluted to $40 \mathrm{~g}$ per $\mathrm{ml}$ or $100 \mathrm{U}$ per $\mathrm{ml}$ in distilled water and added directly. Samples of partially purified hormone from phenol extracts of bovine parathyroids (26) were also examined in bioassay experiments. 3) Vitamin $A$. Vitamin A alcohol was dissolved in ethyl alcohol and diluted 1:100 in culture medium. Ethyl alcohol alone was added to control cultures. 4) Cortisol. Hydrocortisone sodium succinate 4 was

2 Eli Lilly, Indianapolis, Ind.

${ }^{3}$ Kindly provided by Dr. G. Aurbach.

4 Solu-Cortef, Upjohn, Kalamazoo, Mich.

TABLE II

Percentage of total $\mathrm{Ca}^{45}$ initially in embryonic bone that was released into medium after 72 hours incubation under various conditions

\begin{tabular}{|c|c|c|c|c|c|}
\hline \multirow{2}{*}{$\begin{array}{l}\text { Experi- } \\
\text { ment }\end{array}$} & \multirow[b]{2}{*}{ Treatment } & \multirow{2}{*}{$\begin{array}{l}\text { No. of } \\
\text { bone } \\
\text { pairs }\end{array}$} & \multicolumn{2}{|c|}{$\mathrm{Ca}^{45}$ released* } & \multirow{2}{*}{$\begin{array}{l}\text { Treated } \\
\text { Control }\end{array}$} \\
\hline & & & Treated & Control & \\
\hline \multirow{4}{*}{9} & Heat killed & & $\%$ & $\%$ & \\
\hline & ( $1 \mathrm{hr}$ at $\left.48^{\circ} \mathrm{C}\right)$ & 6 & $29 \pm 1 \dagger$ & & 0.50 \\
\hline & PTE, $0.1 \mathrm{U} / \mathrm{ml}$ & 2 & $86 \pm 4$ & $52 \pm 8$ & 1.65 \\
\hline & PTE, $0.5 \mathrm{U} / \mathrm{ml}$ & 2 & $94 \pm 2 \ddagger$ & $63 \pm 1$ & 1.49 \\
\hline \multirow[t]{3}{*}{14} & PTE, $0.01 \mathrm{U} / \mathrm{ml}$ & 3 & $47 \pm 12$ & $36 \pm 4$ & 1.31 \\
\hline & PTE, $0.1 \mathrm{U} / \mathrm{ml}$ & 5 & $51 \pm 4 t$ & $32 \pm 1$ & 1.59 \\
\hline & PTE, $1.0 \mathrm{U} / \mathrm{ml}$ & 5 & $94 \pm 3 t$ & $34 \pm 4$ & 2.76 \\
\hline
\end{tabular}

* Values are mean \pm standard error in this and all subsequent Tables.

† Significantly different from nonpaired controls from the same litter $(p<0.01)$.

‡ Significantly different from paired control bones cultivated in normal human serum $(p<0.01)$. 
dissolved in water and diluted 1:100 in culture medium. No control vehicle was used. 5) Triiodothyronine was dissolved in $0.1 \mathrm{M} \mathrm{NaHCO}$ and diluted $1: 100$ or $1: 200$ in culture medium. $0.1 \mathrm{M} \mathrm{NaHCO}$ alone was used as a control solution. 6) Thyroid cultivation fluid. Pieces of rat thyroid were cultured by the technique previously described for rat parathyroids (27) in media of high or low calcium concentration. The media were then reconstituted by the addition of equal volumes of fresh medium, and the final medium calcium concentration was adjusted to between 7 and $8 \mathrm{mg}$ per $100 \mathrm{ml}$. The effect of reconstituted medium was compared with the effect of fresh medium alone on paired bones. 7) Vitamin $D$. Vitamin $D_{3}$ was added either dissolved in ethyl alcohol as for vitamin $\mathrm{A}$, or as $\mathrm{Vi}-\mathrm{De}_{3}-\mathrm{Hydrosol}, 5$ a water soluble preparation. No control solution was available for Vi-De $\mathrm{D}_{3}$-Hydrosol. 8) Serum. The standard culture

5 Obtained from Dr. A. Wander, Berne, Switzerland.
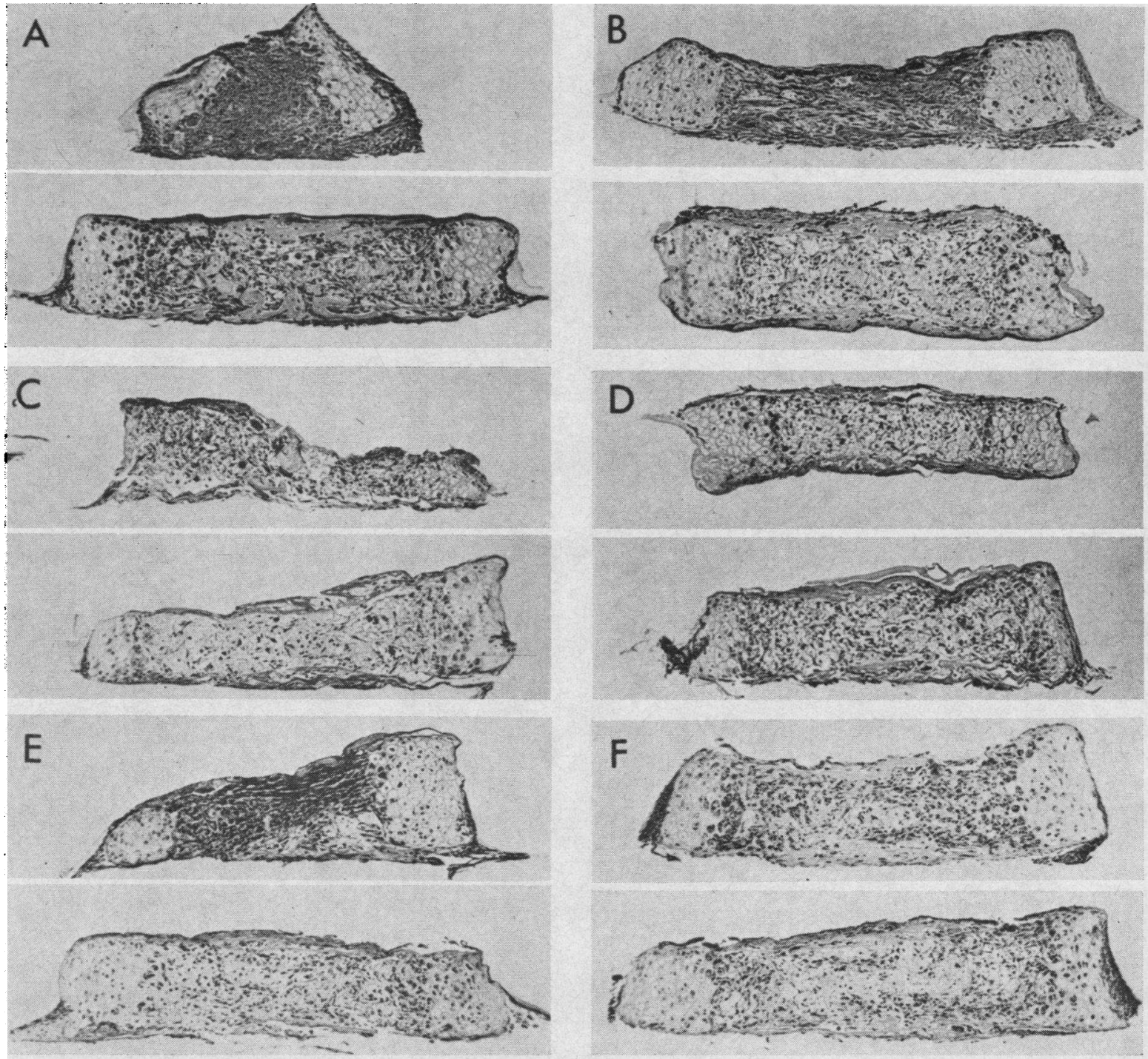

Fig. 1. Effects of parathyroid extract (PTE) and vitamin A with and without cortisol, ANd SERUM From VITAMIN D-DEFICIENT RATS ON BONE RESORPTION. A to D are cultured in media made with normal human serum. Upper bone is treated; lower is paired control. Magnification $\times 70$, hematoxylin and eosin stain. A) Experiment 50: radius, $1.0 \mathrm{U}$ per $\mathrm{ml} \mathrm{PTE} \mathrm{vs.} \mathrm{control.} \mathrm{B)} \mathrm{Experiment} 50$ : radius, $1.0 \mathrm{U}$ per ml PTE plus $200 \mu \mathrm{g}$ per ml cortisol vs. control. C) Experiment 62: radius, $3 \mu \mathrm{g}$ per $\mathrm{ml}$ vitamin A vs. control. D) Experiment $62:$ radius, $3 \mu \mathrm{g}$ per $\mathrm{ml}$ vitamin $\mathrm{A}$ and $200 \mu \mathrm{g}$ per $\mathrm{ml}$ cortisol vs. control. E) Experiment 38: radius, $1.0 \mathrm{U}$ per ml PTE vs. control in medium made with serum from vitamin D-deficient rats given 60,000 $\mathrm{U}$ vitamin $\mathrm{D}$ (Vi-Des-Hydrosol) intravenously 24 hours before bleeding. The response is similar to that obtained in normal rat serum. F) Experiment 38 : radius, $1.0 \mathrm{U}$ per $\mathrm{ml}$ PTE vs. control in medium made with serum from vitamin D-deficient rats. 


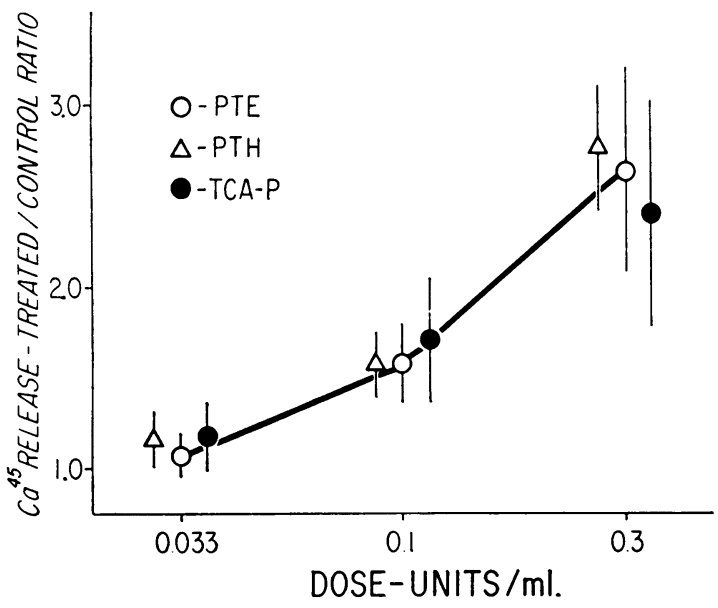

Fig. 2. DOSE RESPONSE DATA FOR THREE PARATHYROID PREPARATIONS IN EXPERIMENT 82. The dose scale is logarithmic and is based on the original estimate of potency of each test material. Vertical lines show the standard error. The reference standard was commercial parathyroid extract (PTE) assayed by the manufacturer at $100 \mathrm{U}$ per $\mathrm{ml}$. The response to purified parathyroid hormone $(\mathrm{PTH})$, originally estimated to have a potency of 2,500 U per mg, was analyzed by a three-dose factorial assay (29) against PTE. The potency estimated by this assay was $2,950 \mathrm{U}$ per $\mathrm{mg}$ with $95 \%$ confidence limits of 1,825 to $6,400 \mathrm{U}$ per $\mathrm{mg}$. A sample of trichloroacetic acid precipitate (TCA-P) from a partially purified phenol extract of bovine parathyroid glands originally estimated to have a potency of $100 \mathrm{U}$ per mg was similarly analyzed. The potency by this analysis was $110 \mathrm{U}$ per $\mathrm{mg}$ with $95 \%$ confidence limits of 57 to $260 \mathrm{U}$ per $\mathrm{mg}$.

medium was made with $50 \%$ normal human serum. The direct effects and the response to $\mathrm{PTE}$ or $\mathrm{PTH}$ were also tested in media made with serum from patients with parathyroid disorders or with hypercalcemia due to cancer, serum from normal and parathyroidectomized rats, and serum from rats maintained on vitamin D-deficient diets $(14,28)$ or given various doses of vitamin $D$.

Design and calculations. In each experiment 32 to 72 bones were cultivated from one or two large litters of eight or more embryos each. Four or more pairs of bones were used for each treatment, one being treated and the other serving as the control. Each treatment was applied in at least two separate experiments. The ulna contained and released more $\mathrm{Ca}^{45}$ than the radius in some experiments, but this difference was sufficiently small so that by alternating treatments, responses in four bones from the same embryo could be compared. The results are expressed as 1) $\mathrm{Ca}^{45}$ release in cpm of $\mathrm{Ca}^{45}$ per $0.1 \mathrm{ml}$ of medium, 2) medium $\mathrm{Ca}$ concentration in $\mathrm{mg}$ per $100 \mathrm{ml}, 3$ ) treated/control ratio of $\mathrm{Ca}^{45}$ release or medium $\mathrm{Ca}$ concentration in paired treated and control cultures, and 4) percentage of $\mathrm{Ca}^{45}$ release calculated from $\mathrm{Ca}^{45}$ released and $\mathrm{Ca}^{45}$ remaining in bone where the latter was measured. Statistical significance was estimated with Student's $t$ test. For PTE and PTH responses the significance of treated/control ratios greater than 1.0 was based on a one-tailed distribution; otherwise a two-tailed test was used. Dose-response experiments were analyzed, with a factorial design for $2 \times 3$ and $2 \times 2$ assays (29).

\section{Results}

Effect of parathyroid extract and parathyroid hormone. The addition of PTE or PTH consistently stimulated bone resorption as indicated by the greater release of $\mathrm{Ca}^{45}$ from the bone to the medium in treated cultures (Table I). Resorption was maximal with doses of 0.3 to $1.0 \mathrm{U}$ per $\mathrm{ml}$. These bones showed disappearance of osteoblasts, complete resorption of the matrix, and proliferation of fibrous tissue and osteoclasts, with a disc of hypertrophied cartilage cells remaining at either end of the explant (Figure 1A). More than $90 \%$ of the $\mathrm{Ca}^{45}$ originally incorporated was released to the medium by the end of cultivation (Table II). Some resorption also occurred in control bones. $\mathrm{Ca}^{45}$ release from living control bones was greater than for bones in which the cells had been killed by heating to 45 to $50^{\circ} \mathrm{C}$. This release was associated with the appearance of scattered osteoclasts, although there was little fibroblastic proliferation, and osteoblasts were still present in the bony shaft. Variability in control resorption accounted for much of the variability in the treated/control ratios for $\mathrm{Ca}^{45}$ release in response to large doses of PTE or PTH (Table II; see also Table V).

Doses of $0.1 \mathrm{U}$ per $\mathrm{ml}$ of PTE or PTH usually caused partial resorption. Responses to purified $\mathrm{PTH}$ were not significantly differenc from the responses to equivalent doses of PTE. Minimal effects were obtained with doses of 0.033 to 0.01 $\mathrm{U}$ per $\mathrm{ml}$. The use of the treated/control ratio of $\mathrm{Ca}^{45}$ release to assay the relative potency of different parathyroid preparations is illustrated in Figure 2 .

Medium Ca concentration was significantly increased with $0.1 \mathrm{U}$ per $\mathrm{ml}$ or more of PTE and $\mathrm{PTH}$. The effect was small compared with $\mathrm{Ca}^{45}$ release, since the medium initially contained about $40 \mu \mathrm{g}$ of $\mathrm{Ca}$ and the bones contained less than 10 $\mu \mathrm{g}$ of $\mathrm{Ca}$, some of which was released in control cultures. Phosphate concentrations in the medium also increased, and the molar ratio of $\mathrm{Ca} / \mathrm{P}$ re- 
BONE RESORPTION IN TISSUE CULTURE

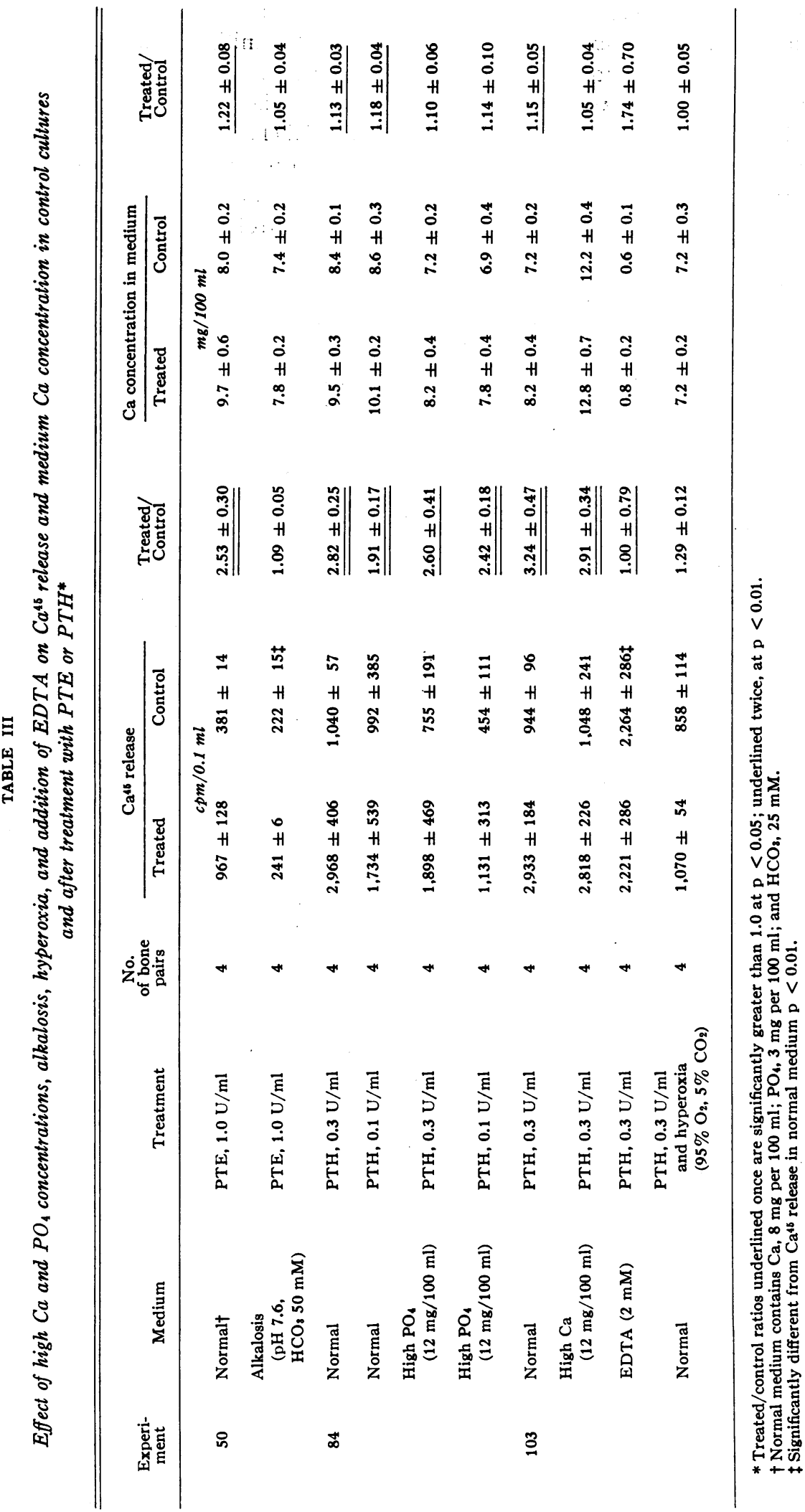


leased in response to PTE was 1.4 to 1.8 , which is similar to the ratio in bone mineral.

Bone size was a critical factor in parathyroid response. The data of these experiments are for bone shafts whose length was 0.9 to $1.3 \mathrm{~mm}$. Smaller bones showed the histologic effects of parathyroid hormone, but contained too little calcium for accurate assay. With the larger bone shafts of older embryos or of 19-day embryos from small litters, ranging from 1.4 to $1.9 \mathrm{~mm}$ in length, addition of $1.0 \mathrm{U}$ per $\mathrm{ml}$ of PTE usually caused only 10 to $20 \%$ more $\mathrm{Ca}^{45}$ release than for paired controls. PTE and PTH regularly increased the medium $\mathrm{Ca}$ concentration and produced typical histologic changes, but there was no extensive resorption of the matrix.

Effect of changing calcium and phosphate concentrations in the medium. When medium phosphate concentration was increased to $12 \mathrm{mg}$ per $100 \mathrm{ml}$ or $4 \mathrm{mM}$, there was a proportional decrease in $\mathrm{Ca}^{45}$ release from both control and treated bones (Table III), such that treated/control ratios were the same as for cultures in normal media. In experiment 84 the ratio of $\mathrm{Ca}^{45}$ release in normal medium to $\mathrm{Ca}^{45}$ release in high phosphate medium for bones from the same embryo was $1.80 \pm .24$ for control cultures, $1.70 \pm$ .21 when $0.3 \mathrm{U}$ per $\mathrm{ml} \mathrm{PTH}$ was added, and $1.53 \pm .16$ when $0.1 \mathrm{U}$ per $\mathrm{ml} \mathrm{PTH}$ was added. These ratios are significantly greater than 1.0 $(p<0.05)$ but not significantly different from each other. Histologically, both control and PTH-treated bones cultivated in high phosphate medium were less cellular and had fewer osteoclasts. When calcium concentration in the medium was varied over a range of 5 to $12 \mathrm{mg}$ per

TABLE IV

Effect of serum from hypercalcemic patients with hyperparathyroidism $(H)$ or bronchogenic cancer $(C)$ compared with normal human serum $(N)$ or serum obtained after successful parathyroidectomy $(P)^{*}$

\begin{tabular}{|c|c|c|c|c|}
\hline Patient & $\begin{array}{c}\text { Patient's } \\
\text { serum } \\
\text { Ca con- } \\
\text { centration }\end{array}$ & $\begin{array}{c}\text { Type of } \\
\text { serum } \\
\text { Treated/ } \\
\text { Control }\end{array}$ & $\begin{array}{l}\text { No. of } \\
\text { bone } \\
\text { pairs }\end{array}$ & $\begin{array}{c}\mathrm{Ca}^{45} \text { release } \\
\text { Treated/Control }\end{array}$ \\
\hline & $\mathrm{mg} / 100 \mathrm{ml}$ & & & \\
\hline Uh & 15.6 & $\mathrm{H} / \mathrm{N}$ & 4 & $0.65 \pm 0.05 \dagger$ \\
\hline Uh & $15.6 / 9.4$ & $\mathrm{H} / \mathrm{P}$ & 7 & $1.00 \pm 0.08$ \\
\hline Mc & 18.9 & $\mathrm{H} / \mathrm{N}$ & 4 & $0.53 \pm 0.10 \dagger$ \\
\hline Do & 15.5 & $\mathrm{C} / \mathrm{N}$ & 3 & $0.76 \pm 0.03 \dagger$ \\
\hline
\end{tabular}

* Medium Ca adjusted to 7 to $9 \mathrm{mg}$ per $100 \mathrm{ml}$.

$\dagger$ Significantly less than 1.0 at $p<0.01$.
$100 \mathrm{ml}$, the final medium $\mathrm{Ca}$ concentration reflected the initial value, but $\mathrm{Ca}^{45}$ release and histologic changes in response to $\mathrm{PTH}$ were similar to those observed in normal media (Table III). When EDTA was added in sufficient concentration $(2 \mathrm{mM})$ to chelate all the calcium initially present in the medium, release of calcium was increased in the control bones, but there was no response to PTH. These bones showed extensive cell necrosis.

Effects of changing $p H$. PTE could stimulate $\mathrm{Ca}$ release and cause typical histologic changes over a range of $\mathrm{pH}$ in the medium of 6.78 to 7.45 . The $\mathrm{pH}$ of medium from treated and control cultures was the same within $0.05 \mathrm{pH} \mathrm{U}$ in six of seven experiments. Medium $\mathrm{Ca}$ concentration was usually higher for both control and treated cultures in media of low $\mathrm{pH}$. When the $\mathrm{pH}$ of the medium was increased to 7.6 by the addition of bicarbonate (Table III), the effect of PTE on $\mathrm{Ca}^{45}$ release was inhibited, and $\mathrm{Ca}^{45}$ release and medium $\mathrm{Ca}$ concentrations of control cultures were decreased. Histologically, the PTE-treated cultures showed only slight fibroblastic proliferation and few osteoclasts.

Effects of hyperoxia. The response to parathyroid hormone was inhibited when bones were cultivated in an atmosphere of 95\% oxygen, 5\% $\mathrm{CO}_{2}$ (Table III). Control bones showed similar values for $\mathrm{Ca}^{45}$ release and medium $\mathrm{Ca}$ concentration whether cultured in $95 \%$ or $20 \%$ oxygen. Histologically, these bones showed a response similar to that seen in alkalosis.

Effects of different sera. Ten samples of serum from patients with hypercalcemia due to parathyroid adenoma or cancer and four samples of hypocalcemic serum from patients with hypoparathyroidism were compared with normal human serum in paired bone cultures. In six instances the pre- and postoperative sera from the same patients were available for comparison. Serum from patients with hypercalcemia did not increase bone resorption, nor did sera from patients with hypocalcemia decrease bone resorption in tissue culture. There were no significant differences when pre- and postoperative sera from the same patients were compared directly. In three instances, bones cultured in serum from patients with marked hypercalcemia actually inhibited $\mathrm{Ca}^{45}$ release when compared with bones cultured 
in normal human sera, but there was no difference in the effect of pre- and postoperative serum from one of these patients (Table IV).

There was no difference in resorption between paired bones cultured in media made with serum from normal or parathyroidectomized rats, and the response to parathyroid extract was similar in both sera. The treated/control ratio for $\mathrm{Ca}^{45}$ release in response to $1.0 \mathrm{U}$ per $\mathrm{ml}$ of PTE was $1.8 \pm .08$ in six experiments in which the medium was made with normal rat serum. Although this ratio is not significantly different from that in normal human serum, the degree of resorption seen histologically in response to PTE was usually less in rat serum (Figure $1 \mathrm{E}$ ). Some samples of human serum appeared to stimulate $\mathrm{Ca}^{45}$ release in both PTE-treated and control bones (Table V; see also experiment 9, Table II). Results with serum from vitamin D-deficient rats are presented below.

Interactions of parathyroid extract, vitamin $A$, and hydrocortisone (Table VI). Vitamin A (3 to $10 \mu \mathrm{g}$ per $\mathrm{ml}$ ) stimulated the release of $\mathrm{Ca}^{45}$ from embryonic bone and increased medium $\mathrm{Ca}$ concentration, but these effects were not so great as those obtained with $1.0 \mathrm{U}$ per $\mathrm{ml}$ of PTE. Histologically, vitamin A-treated bones differed from those treated with parathyroid extract. There was less proliferation of fibroblasts and osteoclasts despite considerable loss of matrix (Figure 1C). When a submaximal dose of PTE (0.1 $\mathrm{U}$ per $\mathrm{ml}$ ) was added to vitamin A-treated cultures, more extensive resorption resulted, leaving only a small remnant of fibroblasts and osteoclasts.

The large dose of cortisol employed in these studies had no effect on $\mathrm{Ca}^{45}$ release from bone or on medium $\mathrm{Ca}$ concentration. Histologically, there were less connective tissue growth and more pyknosis of cartilage cells in these cultures. Addition of cortisol completely inhibited the effects of vitamin A, and the appearance of the bone after combined treatment was like that of treatment with cortisol alone (Figure 1D). Cortisol diminished the response to $1 \mathrm{U}$ per $\mathrm{ml}$ of PTE to some extent; however, the treated bones still showed stimulation of $\mathrm{Ca}^{45}$ release and the typical histologic response to PTE (Figure 1B).

Effects of triiodothyronine and thyroid cultivation fluid. The addition of 0.5 to $1.0 \mu \mathrm{g}$ per

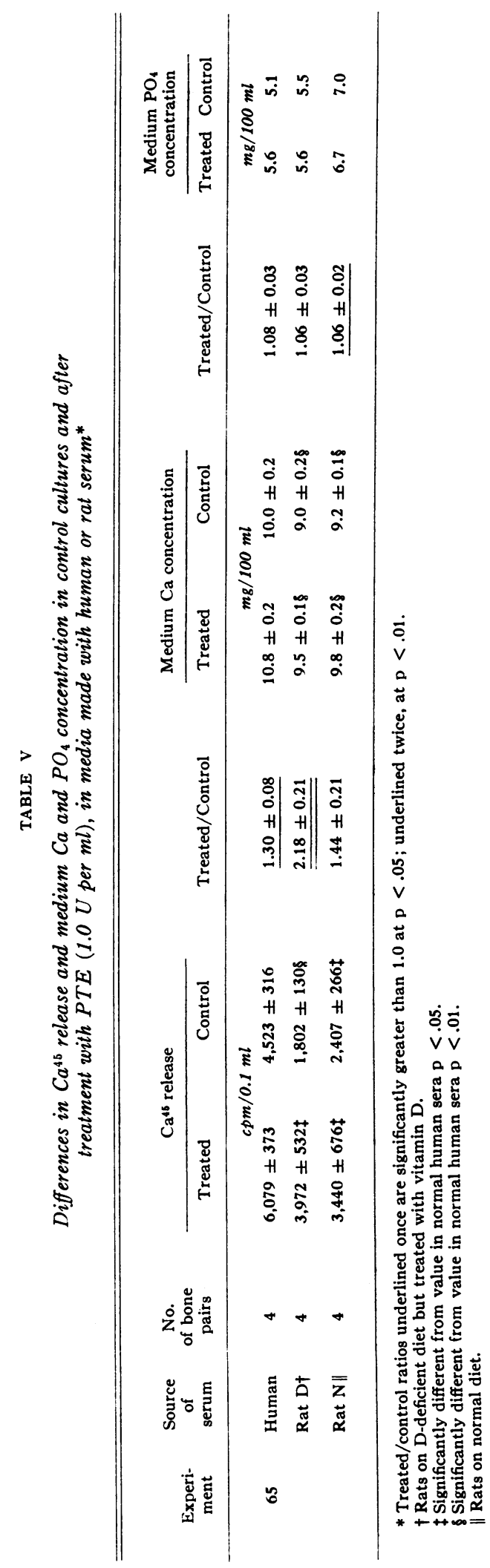




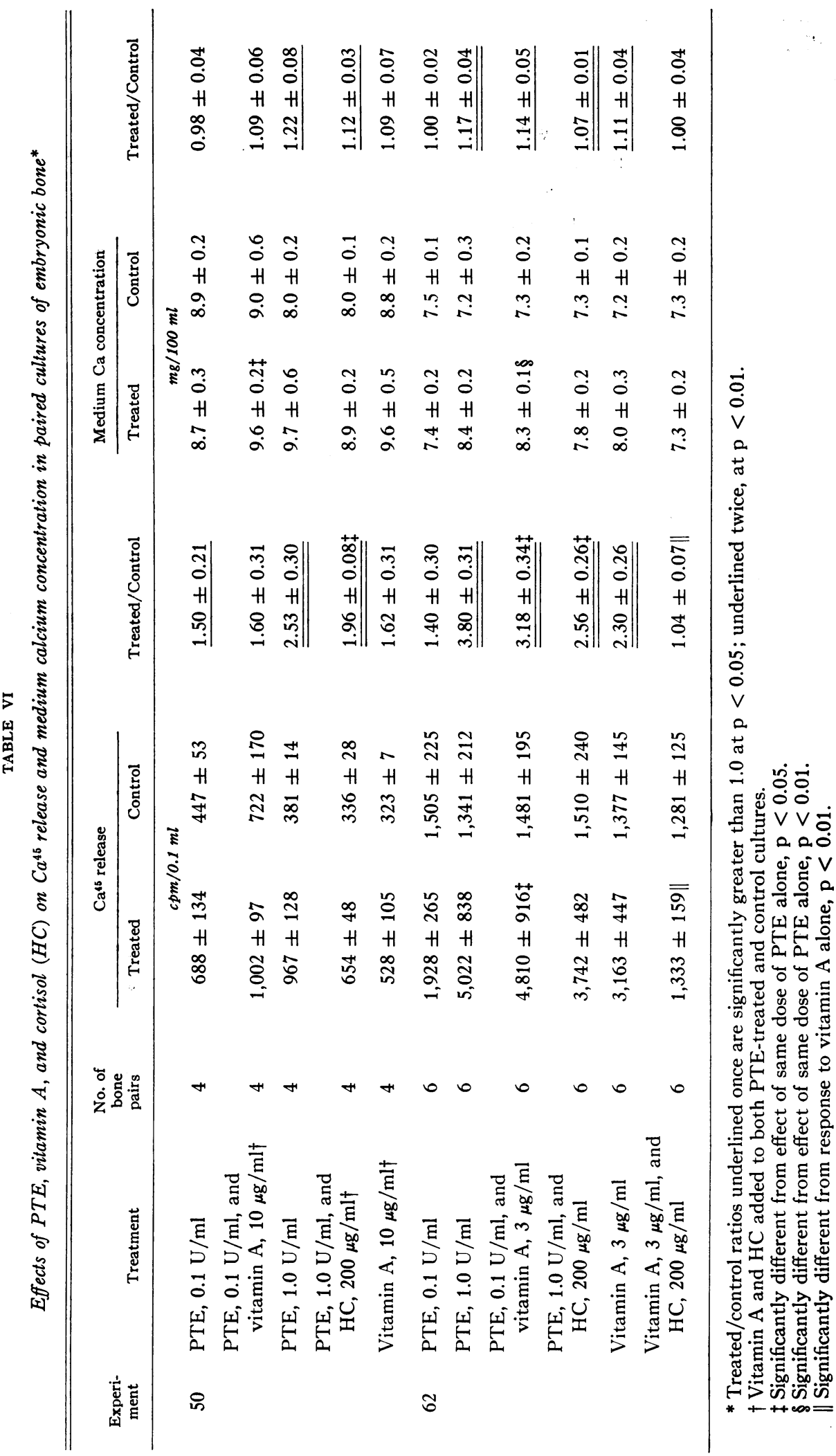




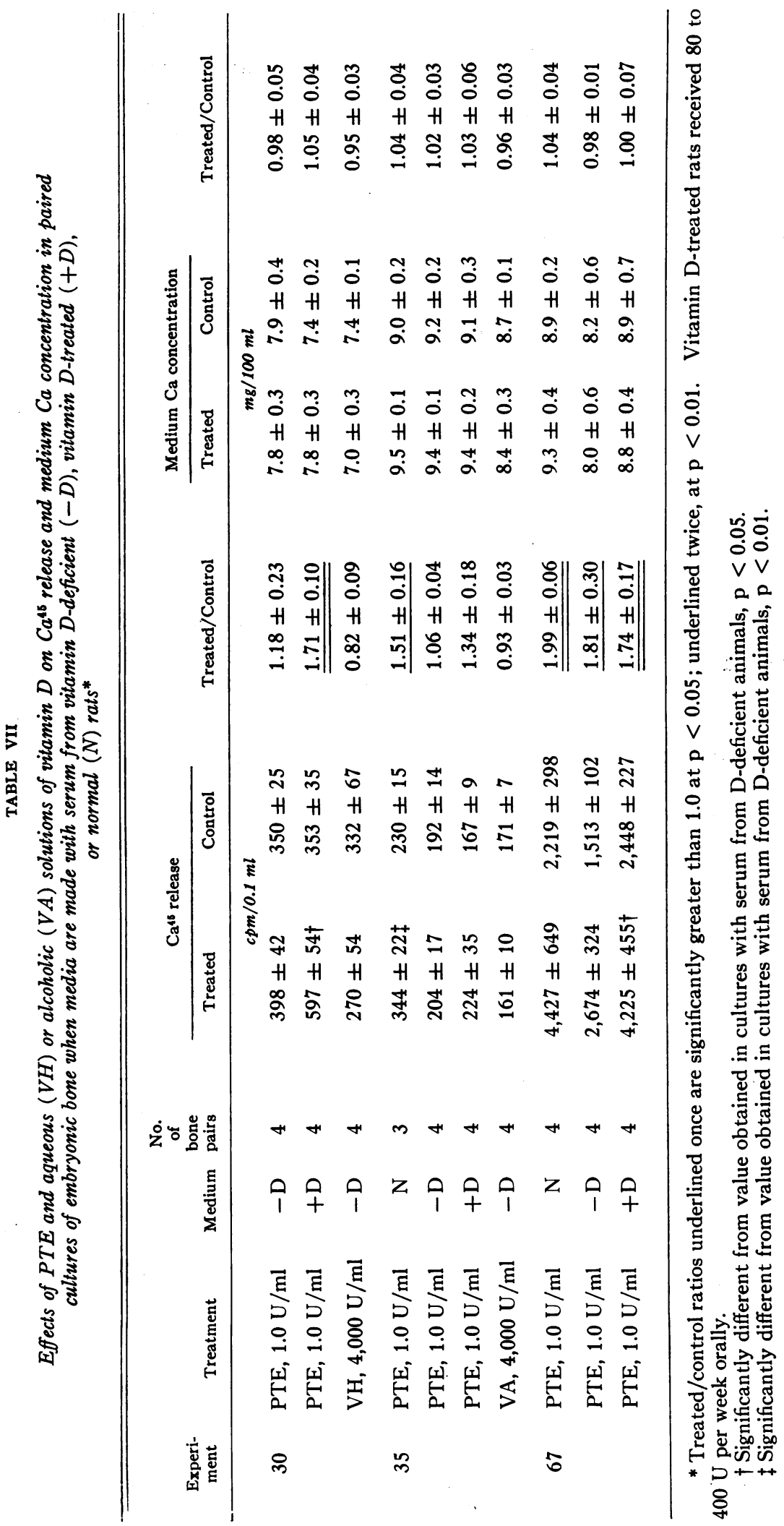


$\mathrm{ml}$ of triiodothyronine did not stimulate bone resorption directly, alter the response to $0.1 \mathrm{U}$ per $\mathrm{ml}$ of PTE, or cause any consistent histologic change. The fluid that had previously been used to cultivate thyroid glands also had no effect on bone resorption whether the original culture had been in medium of high or low $\mathrm{Ca}$ concentration.

Effect of vitamin $D$ and serum from vitamin $D$-deficient animals (Table VII). Large doses of vitamin $\mathrm{D}$ in aqueous or alcoholic solution did not stimulate bone resorption. Histologically, there were some pyknosis of nuclei and death of cells with the larger doses of vitamin D employed. When both vitamin D and PTE were added together, the typical parathyroid response was obtained, apparently unaltered by the presence of vitamin D. Since the direct addition of vitamin $\mathrm{D}$ might not have provided a physiologically active material, the effects of serum from vitamin $\mathrm{D}$-deficient, vitamin $\mathrm{D}$-treated, and normal rats on bone cultures were examined. In five of nine experiments, the addition of $1.0 \mathrm{U}$ per $\mathrm{ml}$ of PTE did not increase $\mathrm{Ca}^{45}$ release significantly and caused little histologic change (Figure $1 \mathrm{~F}$ ) when the medium was made with serum from vitamin $\mathrm{D}$-deficient rats. When serum from animals treated with various doses of vitamin D while on a deficient diet was used, the response to PTE increased significantly in four experiments. However, the PTE response was usually less than that observed in cultures made with serum from normal rats. Serum from vitamin D-deficient animals given a massive dose of $60,000 \mathrm{U}$ of vitamin D intravenously 24 hours before sacrifice did not stimulate bone resorption directly, but did restore the response to PTE (Figure 1E). In two of the four experiments in which PTE did stimulate bone resorption significantly in vitamin D-deficient serum, there was diminished $\mathrm{Ca}^{45}$ release in both control and PTE-treated cultures (for example, experiment 67, Table VII). The difference was similar to that observed with a high phosphate concentration, but in these experiments phosphate concentration remained between 5 and $7 \mathrm{mg}$ per $100 \mathrm{ml}$. When the data were pooled, the mean treated/control ratios for $\mathrm{Ca}^{45}$ release in response to $1 \mathrm{U}$ per $\mathrm{ml}$ of $\mathrm{PTE}$ were $1.47 \pm 0.09$ for vitamin $D$-deficient medium and $1.81 \pm 0.07$ for normal medium $(p<0.01)$.

\section{Discussion}

The ability of parathyroid extract or hormone to stimulate bone resorption in tissue culture can be quantitated and, under suitable conditions, provides a sensitive bioassay for parathyroid activity. However, many other variables can affect bone resorption in control cultures and hence can affect the response to added PTE or PTH. Parathyroid responses were observed in culture media with $\mathrm{pH}$ ranging from 6.8 to 7.4 , calcium concentrations ranging from 5 to $12 \mathrm{mg}$ per $100 \mathrm{ml}$, and phosphate concentrations ranging from 3 to 12 mg per $100 \mathrm{ml}$, although there was a decrease in the amount of calcium released and in the degree of histologic change in response to $\mathrm{PTH}$ in high phosphate medium. The $\mathrm{pH}$ of the medium at the end of cultivation was the same for treated and control cultures. The experiments with EDTA show that removal of calcium from the bone by chelation did not produce a typical parathyroid response, but rather caused marked cell damage. This damage may be due to the low ionized calcium concentration or to chelation of some other essential ion. If parathyroid hormone acted by producing acids at the surface of the bone with the resulting dissolution of mineral and a movement of calcium and phosphate along their concentration gradients into the extracellular fluid, one might expect the response to depend more upon the calcium, phosphate, and particularly the hydrogen ion concentrations in the medium (30). It is likely that the cells at the surface of bone can overcome to some extent limitations imposed by changes in the concentration of ions in the bathing medium.

A marked diminution in parathyroid effect was observed when the medium $\mathrm{pH}$ was above 7.6 or when the cultures were gassed with $95 \%$ oxygen. These effects might be due to interference with the production or release of some metabolic acid required for parathyroid effect, to inactivation of PTH, or to nonspecific toxicity. Goldhaber (5) showed that high oxygen tension could stimulate bone resorption directly. This was not observed in the present study, but only a single high concentration of $\mathrm{O}_{2}$ was tested.

The sensitivity of embryonic bone to parathyroid hormone is sufficient to detect $0.01 \mathrm{U}$ per ml PTE on bioassay. The failure to detect any increase 
in bone resorption in media containing serum from patients with hyperparathyroidism indicates that the concentration of biologically active hormone is probably less than $0.02 \mathrm{U}$ per $\mathrm{ml}$ (20 $\mathrm{mU}$ per $\mathrm{ml}$ ). Serum from patients with severe hypercalcemia actually inhibited bone resorption compared with normal human serum. Berson. Yalow, Aurbach, and Potts (31) have developed a sensitive radioimmunoassay technique that can detect as little as $1.5 \mathrm{mU}$ per $\mathrm{ml}$ of bovine parathyroid hormone. They found concentrations on the order of $3.0 \mathrm{mU}$ per $\mathrm{ml}$ in patients with hyperparathyroidism and were able to detect immunologically active material in some, but not all, normal subjects. Tashjian, Levine, and Munson (32) found no parathyroid hormone activity in human serum using a complement fixation immunoassay technique that can detect 20 to $35 \mathrm{mU}$ per ml.

The sensitivity of the present technique is greater than that of the usual rat assay (33) and requires less hormone, but is less precise and more time consuming. The index of precision $(\lambda)$ of tissue culture assays has been 0.28 to 0.34 compared to 0.18 to 0.28 for rat assays and 0.08 to 0.17 for immunoassay by complement fixation. Nevertheless, the method has been useful in detecting the small amounts of bone-resorbing activity secreted by single rat parathyroids in tissue culture (27) and in assaying other preparations where only a small amount of material is available.

The effects of parathyroid extract on bone in tissue cultures were compared with the effects of vitamin $\mathrm{A}$, cortisol, triiodothyronine, and vitamin D. Vitamin A in large doses was found to stimulate bone resorption as measured by release of previously incorporated $\mathrm{Ca}^{45}$ and by the increase in medium $\mathrm{Ca}$ concentration. Vitamin $\mathrm{A}$ did not produce the histologic picture characteristic of the response to PTE; moreover, a further effect could be produced by adding PTE. Bone explants nearly disappeared when treated with $3 \mu \mathrm{g}$ per $\mathrm{ml}$ of vitamin A plus $0.1 \mathrm{U}$ per $\mathrm{ml}$ of PTE. The effect of vitamin A, but not that of PTE, could be completely inhibited by the addition of cortisol as previously reported by Fell and Thomas (18). The studies of Lucy, Dingle, and Fell (34) suggest that the resorption of cartilage matrix in the presence of vitamin $A$ is the result of the release of proteolytic enzymes in the tissue. Dingle (35) has shown that vitamin A can cause direct release of proteolytic enzymes from a lysosomal preparation of rat liver. Addition of PTE to such a preparation did not cause any release of proteolytic enzyme (36). PTE does not cause the extensive resorption of cartilage that is seen with vitamin $\mathrm{A}$. On the other hand, vitamin A intoxication usually does not lead to hypercalcemia. These findings suggest that parathyroid hormone and vitamin A stimulate bone resorption by quite different mechanisms. The possibility that a synergistic relationship between vitamin A and PTE is of importance in physiologic or pathologic bone resorption deserves further study.

In the present study, cortisol had no direct effect on bone resorption. Cortisol caused a partial inhibition of PTE response, but this may represent a nonspecific toxic effect of the large dose employed. In whole animals, there is evidence that adrenal cortical steroids inhibit bone formation but have little effect on bone resorption (11). In rats, antagonism between the effects of cortisone and PTE has been observed $(10,37,38)$ particularly in renal toxicity; however, cortisone only occasionally reverses the hypercalcemia of hyperparathyroidism in man (39).

In the present study, triiodothyronine did not affect bone resorption directly or alter the response to PTE. In hyperthyroidism, bone turnover is increased and hypercalcemia may occur (12). In tissue culture, triiodothyronine can cause acceleration of differentiation in cartilaginous bone rudiments and has a variable effect on growth $(19,20)$. Gaillard (21) found that thyroxin could affect the cartilage and the osteoblasts in cultures of 14- to 16-day mouse embryo radius, but did not cause an increase in osteoclasts or resorption of bone matrix.

Although the role of bone in the hypercalcemia of vitamin $\mathrm{D}$ intoxication has been questioned (14), there is evidence for direct stimulation of bone resorption by excessive amounts of vitamin $\mathrm{D}(5,16)$. There is also evidence that the parathyroid glands cannot maintain normal serum calcium concentration in the absence of vitamin D. In vitamin D-deficient rats with hypocalcemia there is little change in serum calcium concentration in response to exogenous PTE $(40,41)$. Apparently increased endogenous hormone also fails to maintain serum calcium in vitamin $\mathrm{D}$ deficiency, 
since hypocalcemia develops despite an increase in parathyroid activity (42).

In the present study, no direct effect of vitamin $\mathrm{D}$ on bone resorption was demonstrated. Some dependence of parathyroid hormone effect on vitamin $\mathrm{D}$ or its metabolic products was suggested by the observation that the PTE response was decreased or absent in some experiments when bones were cultured in media containing serum from vitamin $\mathrm{D}$-deficient animals. The variable results could reflect differences in the amount of vitamin $\mathrm{D}$ in the embryos, which came from normally fed mothers. Differences in PTE response have also been observed with different human and rat sera that could not be ascribed to differences in vitamin $\mathrm{D}$ intake or in endogenous parathyroid activity in the donor animals. Some samples of human serum were found to stimulate bone resorption to a considerable degree without added PTE.

In an attempt to identify the factors responsible for such resorption, serum fractions have been separated by gel filtration and assayed for boneresorbing activity (43). Bone-resorbing activity has been found in low molecular weight peptide fractions of normal serum and also in serum from parathyroidectomized animals. Further studies on such materials may enable us to improve the precision of bioassay in organ cultures of embryonic bone by controlling their effects and to identify factors other than parathyroid tissue that may regulate bone resorption physiologically.

\section{Summary}

1. The addition of 0.01 to $1.0 \mathrm{U}$ per $\mathrm{ml}$ of parathyroid extract (PTE) or purified parathyroid hormone $(\mathrm{PTH})$ to the medium was found to stimulate resorption in 72-hour cultures of bone shafts of radius and ulna from 19-day rat embryos.

2. Radioactive calcium injected into pregnant rats was incorporated in the embryonic bone. Resorption could then be measured in cultures as the release of $\mathrm{Ca}^{45}$ and the effect of $\mathrm{PTH}$ or PTE treatment as the ratio of $\mathrm{Ca}^{45}$ released from treated bones to that released from paired controls (treated/control ratio).

3. Calcium concentration in the medium could be varied from 5 to $12 \mathrm{mg}$ per $100 \mathrm{ml}$ and $\mathrm{pH}$ from 6.8 to 7.4 without inhibiting parathyroid response. In media of high phosphate concentration (12 mg per $100 \mathrm{ml}$ ) absolute values for $\mathrm{Ca}$ release were decreased in both control and PTHtreated bones, but the treated/control ratio was little altered.

4. Hyperoxia $\left(95 \% \mathrm{O}_{2}, 5 \% \mathrm{CO}_{2}\right)$ or a high $\mathrm{pH}$ (7.60) markedly diminished the parathyroid response. A high $\mathrm{pH}$ also decreased $\mathrm{Ca}^{45}$ release from control bones. The addition of $2 \mathrm{mM}$ Edathamil (EDTA) increased $\mathrm{Ca}^{45}$ release from control bones and abolished the PTH effect; these explants were not well preserved.

5. Variations in resorption were encountered when bones were cultivated in media made with different samples of human and rat serum. These differences could not be ascribed to variations in parathyroid activity. There was no difference in bone resorption between paired bones cultured in media made from serum from patients with hyperparathyroidism before and after parathyroidectomy.

6. Vitamin A (3 to $10 \mu \mathrm{g}$ per $\mathrm{ml}$ ) increased release of $\mathrm{Ca}^{45}$ and stable calcium from embryonic bone. The effect was less than that of a maximal dose of PTE (1 U per ml). Addition of PTE (0.1 $\mathrm{U}$ per $\mathrm{ml}$ ) to vitamin $\mathrm{A}$ further enhanced resorption.

7. A large dose of cortisol (200 $\mu \mathrm{g}$ per $\mathrm{ml}$ ) had no apparent effect on cultures of embryonic bone. This dose inhibited the effect of vitamin A completely but only partly inhibited the PTE effect.

8. Triiodothyronine ( 0.5 and $1.0 \mu \mathrm{g}$ per $\mathrm{ml})$ had no effect on bone resorption directly or on the response to PTE. Culture fluid from rat thyroids similarly had no effect on bone resorption.

9. The addition of vitamin $\mathrm{D}$ in alcoholic or aqueous solution or sera from animals treated with large doses of vitamin $\mathrm{D}$ did not stimulate bone resorption directly. The response to PTE was diminished when the culture medium was made with the serum from vitamin D-deficient rats compared with the culture media made with sera from vitamin $\mathrm{D}$-treated rats or rats on a normal diet.

\section{Acknowledgments}

I wish to thank Dr. W. Y. W. Au and Dr. G. Engstrom for providing some of the sera from vitamin D-deficient and vitamin D-treated animals, and Mr. J. E. O'Brien and Mrs. A. Doty for valuable technical assistance. 


\section{References}

1. Raisz, L. G. Stimulation of bone resorption by parathyroid hormone in tissue culture. Nature (Lond.) 1963, 197, 1015.

2. Barnicot, N. A. The local action of the parathyroid and other tissues on bone in intracerebral grafts. J. Anat. (Lond.) 1948, 82, 233.

3. Chang, H. Y. Grafts of parathyroid and other tissues to bone. Anat. Rec. 1951, 111, 23.

4. Gaillard, P. Parathyroid and bone in tissue culture in The Parathyroids, R. T. Greep and R. V. Talmage, Eds. Springfield, Ill., Charles C Thomas, 1961, p. 20.

5. Goldhaber, P. Some chemical factors influencing bone resorption in tissue culture in Mechanisms of Hard Tissue Destruction, R. F. Sognnaes, Ed. Washington, American Association for the Advancement of Science (Publication no. 75), 1963, p. 609.

6. Raisz, L. G., W. Y. W. Au, and J. Tepperman. Effect of changes in parathyroid activity on bone metabolism in vitro. Endocrinology 1961, 68, 783.

7. Wolbach, S. B. Vitamin-A deficiency and excess in relation to skeletal growth. J. Bone Jt Surg. 1947, 29, 171.

8. Cohen, J., C. L. Maddock, and S. B. Wolbach. The effect of parathyroidectomy on the evolution of hypervitaminosis A in rats. Arch. Path. 1955, 59, 723.

9. Irving, J. T. The effects of avitaminosis and hypervitaminosis $A$ upon the incisor teeth and incisal alveolar bone of rats. J. Physiol. (Lond.) 1949, 108, 92.

10. Laron, Z., J. P. Muhlethaler, and R. Klein. The interrelationship between cortisone and parathyroid extract in rats. Arch. Path. 1958, 65, 125.

11. Clark, I., R. F. Geoffroy, and W. Bowers. Effects of adrenal cortical steroids on calcium metabolism. Endocrinology 1959, 64, 849.

12. Krane, S. M., G. L. Brownell, J. B. Stanbury, and H. Corrigan. The effect of thyroid disease on calcium metabolism in man. J. clin. Invest. 1956, $35,874$.

13. Aubert, J.-P., A. G. Cherian, M. S. Moukhtar, and G. Milhaud. Etude du métabolisme du calcium chez le rat à l'aide de calcium 45 . V. La thyroparathyroidectomie et l'effet de la thyroxine et de la parathormone. Biochem. Pharmacol. 1964, 13, 31.

14. Harris, L. J. Vitamin D and bone in The Biochemistry and Physiology of Bone, G. H. Bourne, Ed. New York, Academic Press, 1956, p. 590.

15. Barnicot, N. A. The local action of vitamin $A$ on bone. J. Anat. (Lond.) 1950, 84, 374.

16. Barnicot, N. A. The local action of calciferol and oestradiol on bone. J. Anat. (Lond.) 1951, 85, 120.
17. Fell, H. B., and E. Mellanby. The effect of hypervitaminosis $\mathrm{A}$ on embryonic limb-bones cultivated in vitro. J. Physiol. (Lond.) 1952, 116, 320.

18. Fell, H. B., and L. Thomas. The influence of hydrocortisone on the action of excess vitamin $A$ on limb bone rudiments in culture. J. exp. Med. 1961, $114,343$.

19. Fell, H. B., and E. Mellanby. The effect of L-triiodothyronine on the growth and development of embryonic chick limb-bones in tissue culture. J. Physiol. (Lond.) 1956, 133, 89.

20. Lawson, $K$. The differential growth response of embryonic chick limb-bone rudiments to triiodothyronine in vitro. 1. Stage of development and organ size. J. Embryol. exp. Morph. 1961, 9, 42.

21. Gaillard, P. J. Observations on the effect of thyroid and parathyroid secretions on explanted mouse radius rudiments. Develop. Biol. 1963, 7, 103.

22. Eagle, H. Nutrition needs of mammalian cells in tissue culture. Science 1955, 122, 501.

23. Chen, P. S., Jr., T. Y. Toribara, and H. Warner. Microdetermination of phosphorus. Analyt. Chem. 1956, 28, 1756.

24. Beale, R. N., and J. O. Bostrom. Sensitive methods for the titrimetric microdetermination of biological calcium and magnesium. J. clin. Path. 1963, 16, 252.

25. Chen, P. S., Jr. Liquid scintillation counting of $\mathrm{C}^{14}$ and $\mathrm{H}^{3}$ in plasma and serum. Proc. Soc. exp. biol. (N. Y.) 1958, 98, 546.

26. Aurbach, G. D. Isolation of parathyroid hormone after extraction with phenol. J. biol. Chem. 1959, 234, 3179.

27. Raisz, L. G. Regulation by calcium of parathyroid growth and secretion in vitro. Nature (Lond.) 1963, 197, 1115.

28. Steenbock, H., and D. C. Herting. Vitamin D and growth. J. Nutr. 1955, 57, 449.

29. Bliss, C. I. The Statistics of Bioassay. New York, Academic Press, 1952.

30. Schartum, S., and G. Nichols, Jr. Concerning pH gradients between the extracellular compartment and fluids bathing the bone mineral surface and their relation to calcium ion distribution. J. clin. Invest. 1962, 41, 1163.

31. Berson, S. A., R. S. Yalow, G. D. Aurbach, and J. R. Potts, Jr. Immunoassay of bovine and human parathyroid hormone. Proc. nat. Acad. Sci. (Wash.) 1963, 49, 613.

32. Tashjian, A. H., Jr., L. Levine, and P. L. Munson. Immunoassay of parathyroid hormone by quantitative complement fixation. Endocrinology 1964, 74, 244.

33. Munson, P. L. Biological assay of parathyroid hormone in The Parathyroids, R. O. Greep and R. V. Talmage, Eds. Springfield, Ill, Charles C Thomas, 1961, p. 94.

34. Lucy, J. A., J. T. Dingle, and H. B. Fell. Studies on the mode of action of excess of vitamin A. 2 . A possible role of intracellular proteases in the 
degradation of cartilage matrix. Biochem. J. 1961, 79, 500.

35. Dingle, J. T. Studies on the mode of action of excess of vitamin A. 3. Release of a bound protease by the action of vitamin A. Biochem. J. 1961, 79, 509.

36. Dingle, J. T., and L. G. Raisz. Unpublished observations.

37. Bradford, R. H., R. P. Howard, W. Joel, and M. R. Shetlar. Antagonistic effects of parathyroid extract and cortisone. Arch. Path. 1960, 69,382 .

38. Stoerk, H. C., A. C. Peterson, and V. C. Jelinek. The blood calcium lowering effect of hydrocortisone in parathyroidectomized rats. Proc. Soc. exp. Biol. (N. Y.) 1963, 114, 690.
39. Dent, C. E. Some problems of hyperparathyroidism. Brit. Med. J. 1962, 2, 1419, 1495.

40. Harrison, H. C., H. E. Harrison, and E. A. Park. Vitamin D and citrate metabolism; effect of vita$\min \mathrm{D}$ in rats fed diets adequate in both calcium and phosphorus. Amer. J. Physiol. 1958, 192, 432.

41. Rasmussen, H., H. DeLuca, C. Arnaud, C. Hawker, and $M$. von Stedingk. The relationship between vitamin $\mathrm{D}$ and parathyroid hormone. J. clin. Invest. 1963, 42, 1940.

42. Au, W. Y. W., and L. G. Raisz. Parathyroid activity in vitamin D-deficient rats (abstract). Clin. Res. 1964, 12, 261.

43. Stern, P. H., and L. G. Raisz. Unpublished observations. 